\title{
Hepatic P450 Enzyme Activity, Tissue Morphology and Histology of Mink (Mustela vison) Exposed to Polychlorinated Dibenzofurans
}

\author{
Jeremy N. Moore $\cdot$ John L. Newsted $\cdot$ Markus Hecker $\cdot$ Matthew J. Zwiernik $\cdot$ \\ Scott D. Fitzgerald $\cdot$ Denise P. Kay $\cdot$ Xiaowei Zhang $\cdot$ Eric B. Higley $\cdot$ \\ Lesa L. Aylward · Kerrie J. Beckett · Robert A. Budinsky · Steven J. Bursian · \\ John P. Giesy
}

Received: 22 April 2008/ Accepted: 8 September 2008/Published online: 21 May 2009

(C) The Author(s) 2009. This article is published with open access at Springerlink.com

\begin{abstract}
Dose- and time-dependent effects of environmentally relevant concentrations of 2,3,7,8-tetrachlorodibenzop-dioxin equivalents (TEQ) of 2,3,7,8-tetrachlorodibenzofuran
\end{abstract}

J. N. Moore $(\bowtie) \cdot$ M. J. Zwiernik · X. Zhang .

E. B. Higley · J. P. Giesy

Department of Zoology, National Food Safety and Toxicology Center, Michigan State University, East Lansing, MI 48824,

USA

e-mail: moorej42@msu.edu

M. J. Zwiernik

e-mail: zwiernik@msu.edu

\section{Zhang}

e-mail: howard50003250@yahoo.com

E. B. Higley

e-mail: higleyer@msu.edu

J. N. Moore · J. L. Newsted - M. J. Zwiernik ·

S. J. Bursian

Department of Animal Science, Center for Integrative

Toxicology, Michigan State University, East Lansing, MI 48824, USA

J. L. Newsted

e-mail: jnewsted@entrix.com

\section{S. J. Bursian}

email: bursian@msu.edu

J. L. Newsted · D. P. Kay

ENTRIX, Inc., Okemos, MI 48823, USA

D. P. Kay

e-mail: dkay@entrix.com

M. Hecker · J. P. Giesy

Department of Biomedical Veterinary Sciences and Toxicology

Centre, University of Saskatchewan, Saskatoon, SK,

Canada S7N 5B3
(TCDF), 2,3,4,7,8-pentachlorodibenzofuran (PeCDF), or a mixture of these two congeners on hepatic P450 enzyme activity and tissue morphology, including jaw histology, of

M. Hecker

ENTRIX, Inc., Saskatoon, SK S7N 5B3, Canada

e-mail: mhecker@entrix.com

S. D. Fitzgerald

Department of Pathobiology and Diagnostic Investigation,

Diagnostic Center for Population and Animal Health,

Michigan State University, East Lansing,

MI 48824, USA

e-mail: Fitzgerald@dcpah.msu.edu

L. L. Aylward

Summit Toxicology, Falls Church, VA 22044, USA

e-mail: laylward@summittoxicology.com

\section{K. J. Beckett}

Stantec Consulting Services, Inc., Topsham,

ME 04086, USA

e-mail: kerrie.beckett@stantec.com

\section{R. A. Budinsky}

The Dow Chemical Company, Midland,

MI 48642, USA

e-mail: rabudinsky@dow.com

\section{J. P. Giesy}

Department of Biology and Chemistry,

City University of Hong Kong,

Kowloon, Hong Kong, SAR China

email: jgiesy@aol.com

J. P. Giesy

School of Environment, Nanjing University,

Nanjing 210093, China 
adult ranch mink were determined under controlled conditions. Adult female ranch mink were fed either TCDF $(0.98,3.8$, or $20 \mathrm{ng} \mathrm{TEQ}_{\mathrm{TCDF}} / \mathrm{kg}$ bw/day) or $\operatorname{PeCDF}(0.62,2.2$, or $9.5 \mathrm{ng}$ $\mathrm{TEQ}_{\mathrm{PeCDF}} / \mathrm{kg}$ bw/day), or a mixture of TCDF and PeCDF (4.1 ng TEQ $\mathrm{TCDF}_{\mathrm{T}} / \mathrm{kg}$ bw/day and $2.8 \mathrm{ng} \mathrm{TEQ}_{\mathrm{PeCDF}} / \mathrm{kg}$ bw/day, respectively) for 180 days. Doses used in this study were approximately eight times greater than those reported in a parallel field study. Activities of the cytochrome P450 1A enzymes, ethoxyresorufin $O$-deethylase (EROD) and methoxyresorufin $O$-deethylase (MROD) were significantly greater in livers of mink exposed to TCDF, PeCDF, and a mixture of the two congeners; however, there were no significant histological or morphological effects observed. It was determined that EROD and MROD activity can be used as sensitive biomarkers of exposure to PeCDF and TCDF in adult female mink; however, under the conditions of this study, the response of EROD/MROD induction occurred at doses that were less than those required to cause histological or morphological changes.

Recently, there has been concern about the concentrations of polychlorinated dibenzofurans (PCDFs), polychlorinated dibenzo- $p$-dioxins (PCDDs), and polychlorinated biphenyls (PCBs) in floodplain soil and sediment from the Tittabawassee River (Hilscherova et al. 2003). The Tittabawassee River flows into the Saginaw River and Saginaw Bay, Michigan, USA as part of the Lake Huron watershed. Both field and laboratory-based studies have been conducted to assess the potential risks of these concentrations of PCDD, $\mathrm{PCDF}$, and PCBs on terrestrial and aquatic organisms (Zwiernik et al. 2008a).

The mink (Mustela vison) has been utilized as a sentinel species for ecological risk assessments at sites where contaminants of concern are chemicals that can bind to the aromatic hydrocarbon receptor (AhR) such as 2,3,7,8-tetrachlorodibenzo- $p$-dioxin (TCDD) and structurally similar compounds (Blankenship et al. 2008; Basu et al. 2007; Giesy et al. 1994; Tillitt et al. 1996). The mink is considered to be among the more sensitive mammals to TCDD and related compounds (Beckett et al. 2008; Hochstein et al. 1988, 1998). Mink have a relatively great potential for exposure to these persistent, bioaccumulative chemicals (Basu et al. 2007).

An ecological risk assessment using previously established toxicity reference values (TRVs) derived primarily from studies of the effects of TCDD and other AhR-active compounds on mink (Blankenship et al. 2008) and concentrations of TCDD equivalents (TEQs) in the diet and tissues of mink inhabiting the Tittabawassee River has been conducted (Zwiernik et al. 2008a). This study indicated that mink might be at risk of being adversely affected by these compounds, with hazard quotients between $<1$ and 10 being calculated. However, despite accumulating relatively great concentrations of 2,3,4,7,8-pentachlorodibenzofuran (PeCDF) and 2,3,7,8-tetrachlorodibenzofuran (TCDF) in their livers, the condition of individual mink from the more highly contaminated areas of the Tittabawassee River was comparable or superior to that of mink collected in reference areas and the population was robust (Zwiernik et al. 2008a). The inconsistency between the apparent healthy population and the elevated hazard quotient (HQ) estimates might be due to several factors, including the following: (1) The World Health Organization (WHO) toxic equivalent factor (TEF) values and resulting TEQ concentrations are conservative and might have overestimated risk; (2) the toxicity reference values (TRVs) used to estimate the HQs might not have been accurate for mink due to lack of toxicological information for the dominant PCDF congeners identified in mink at the site relative to data available in the literature to derive TEFs; and (3) uptake rates, metabolism, excretion, and disposition of TCDF and PeCDF might differ from TCDD or PCBs that have been studied in mink (Beckett et al. 2008; Zwiernik et al. 2008b).

A 180-day dietary study was conducted to (1) determine rates of assimilation and distribution of environmentally relevant doses of TCDF, PeCDF or a combination of the two congeners in liver tissue of mink (Zwiernik et al. 2008b) and (2) examine the relationship between chemical exposure and hepatic cytochrome P4501A enzyme activities, potential functional indicators of exposure to AhR agonists (Hahn 1998; Kawajiri and Fujii-Kuriyama 2007; Whitlock 1999). Ethoxyresorufin $O$-deethylase (EROD) activity is most directly associated with the induction of hepatic activity of the cytochrome P4501A1 enzymes, whereas methoxyresorufin $O$-deethylase (MROD) activity is more associated with P4501A2 enzymes. However, although both enzymes can metabolize either substrate to some extent, the metabolism of both substrates provides valuable information as to $\mathrm{P} 4501 \mathrm{~A}$ activity in an organism relative to its exposure to xenobiotics. The study was conducted to also (3) examine relationships between EROD and MROD activity in liver to other morphological and histological changes in mink. This article presents the results of the effects of TCDF and PeCDF on hepatic EROD and MROD activities and selected morphological and histological parameters in mink.

\section{Material and Methods}

Mink Husbandry, Exposure, and Necropsy

Adult, female, ranch mink were randomly assigned and housed individually in wire-mesh breeder cages $(61 \mathrm{~cm}$ $\mathrm{L} \times 76 \mathrm{~cm} \mathrm{~W} \times 46 \mathrm{~cm} \mathrm{H})$ with wooden nest boxes 
Table 1 Daily dose and concentrations of TCDF and/or PeCDF in the liver of mink (Mustela vison)

\begin{tabular}{clll}
\hline Treatment & Daily dose & $\begin{array}{l}\text { Liver concentration } \\
(\text { ng TEQ/kg, ww })^{\mathrm{a}}\end{array}$ \\
\cline { 3 - 4 } & $($ ng TEQ/kg bw/d) & 0 day & $\begin{array}{l}\text { Mean of } 90 \\
\text { and } 180 \text { days }\end{array}$ \\
\hline Control & & & \\
TCDF & $<$ LOD $^{\mathrm{b}}$ & $<\mathrm{LOD}^{\mathrm{b}}$ & $<\mathrm{LOD}^{\mathrm{b}}$ \\
PeCDF & $<\mathrm{LOD}^{\mathrm{b}}$ & $<\mathrm{LOD}^{\mathrm{c}}$ & $<\mathrm{LOD}^{\mathrm{c}}$ \\
TCDF & 0.98 & NA & $1.2 \pm 0.27$ \\
& 3.8 & NA & $2.3 \pm 0.22$ \\
& 20 & NA & $7.1 \pm 1.1$ \\
PeCDF & 0.62 & NA & $52 \pm 18$ \\
& 2.2 & NA & $270 \pm 25$ \\
& 9.5 & NA & $1600 \pm 530$ \\
Mixture of & & & $1.4 \pm 0.24$ \\
TCDF & 4.1 & NA & $360 \pm 80$ \\
PeCDF & 2.8 & NA &
\end{tabular}

Note: Each treatment group had six mink and the control group had eight mink. Control animals were sampled at 0, 90, and 180 days; three treated animals per single congener dose group were sampled at 90 and 180 days. Two mink livers in the mixture group were analyzed at 90 days and three mink livers were analyzed at 180 days. All concentrations were converted to 2,3,7,8-TCDD equivalents (TEQs) using TEFs of 0.3 for PeCDF and 0.1 for TCDF (Van den Berg et al. 2006). NA indicates that samples were not collected

${ }^{\text {a }}$ Liver concentrations are presented as mean $\pm 1 \mathrm{SD}$

${ }^{\text {b }}$ LOD $=0.01 \mathrm{ng} \mathrm{TEQ} / \mathrm{kg}$, ww

${ }^{c} \mathrm{LOD}=0.1 \mathrm{ng} \mathrm{TEQ} / \mathrm{kg}$, ww

$(30 \mathrm{~cm} \mathrm{~L} \times 22.5 \mathrm{~cm} \mathrm{~W} \times 25 \mathrm{~cm} \mathrm{H})$ within an indoor facility at Michigan State University (MSU). A total of 50 female mink were distributed among 8 treatments with 6 individuals in each of 7 furan-dosed groups (3 TCDF groups, 3 PeCDF groups, and 1 TCDF plus PeCDF group) and 8 female mink in the control group. Doses were expressed as TEQs (Table 1) calculated by use of TEFs reported by Van den Berg et al. (2006). The test chemical for each treatment was dissolved in hexane to produce a stock solution, and aliquots of the stock were then diluted appropriately with $100 \mathrm{~mL}$ corn oil. The corn oil containing the test chemical was added to the water component of the mink diet and mixed well in a paddle mixer prior to the addition of the other feed ingredients. After the addition of all of the dietary ingredients, the feed was mixed for an additional $20 \mathrm{~min}$. Each morning for 180 days, $25 \mathrm{~g}$ of feed containing the furan congener(s) were given to each animal. This procedure ensured complete ingestion of the contaminated feed, eliminating the need to measure daily feed consumption in order to estimate doses. After this feed was consumed, an additional $100 \mathrm{~g}$ of uncontaminated feed were given to each animal. Water was provided ad libitum. Full-spectrum lighting controlled by a timer simulated the natural light/dark cycle for the Eastern Standard Time Zone. Temperature was maintained between $13^{\circ} \mathrm{C}$ and $28^{\circ} \mathrm{C}$ and humidity ranged from $26 \%$ to $91 \%$. Mink were observed daily for signs of toxicity including a decrease in feed consumption and lethargy. Individual body masses $(\mathrm{g})$ were measured at the beginning of the study (January 31, 2006) and every 30 days thereafter.

Three animals from the control group were euthanized by asphyxiation with carbon dioxide at initiation of the exposure ( 0 day) and three animals from each of the eight treatment groups were euthanized at 90 and 180 days of exposure for subsequent necropsy. Body mass (g) and length $(\mathrm{cm})$, including and excluding the tail, were recorded for each female mink. Mink were examined externally and internally for overall condition, nutritional status, and the presence of gross abnormalities. Livers were removed and weighed. Subsamples of the liver were frozen in liquid nitrogen for subsequent measurement of EROD and MROD activities. Approximately $2.0 \mathrm{~g}$ of liver tissue was placed in a $10 \%$ formalin-saline solution (10\% formalin in $0.9 \%$ sodium chloride) for histological examination. The remaining liver was placed in $\mathrm{I}_{-} \mathrm{Chem}{ }^{\circledR}$ jars (I-Chem, New Castle, DE, USA) and frozen at $-20^{\circ} \mathrm{C}$ for subsequent determination of TCDF and PeCDF concentrations using high-resolution gas chromatography/mass spectrometry (HR-GC/MS). In addition, the spleen, kidneys, thymus, mesenteric lymph node, and brain were removed and preserved for subsequent histological examination. The head was placed in formalin-saline solution for subsequent histological examination of mandibular and maxillary squamous epithelial cell proliferation as described by Beckett et al. (2005). The lesion was graded as mild, moderate, or severe based on the number and size of foci of squamous cell proliferation in the maxilla and mandible (Beckett et al. 2005). The MSU Institutional Animal Care and Use Committee approved this study (AUF 12/05165-00).

\section{Chemicals and Reagents}

Both PeCDF and TCDF were obtained from Accustandard Inc. (New Haven, CT, USA) and dissolved in hexane to produce a stock solution. Working solutions and dilutions of PeCDF and TCDF were prepared in pesticide residue analysis-grade OmniSolv $n$-hexane (EM Science, Lawrence, KS, USA). For biochemical analyses, 7-ethoxyresorufin (7-ER) was obtained from Molecular Probes (Eugene, OR, USA) and 7-methoxyresorufin (7-MR) and resorufin were obtained from Sigma-Aldrich (St. Louis, MO, USA). All other biochemical reagents, including NADPH, were obtained from Sigma-Aldrich and were reagent grade or better unless stated otherwise. 
EROD and MROD Quantification

Liver microsomes were prepared by homogenizing $0.5 \mathrm{~g}$ of liver in Tris buffer $(0.05 \mathrm{M}$ Tris and $1.15 \% \mathrm{KCl}, \mathrm{pH} 7.5)$ and centrifuged to obtain the microsomal fraction. The microsomal pellet was resuspended in microsomal stabil-

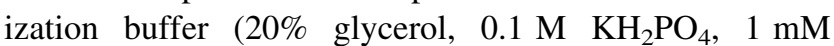
EDTA, and $1 \mathrm{mM}$ dithiothreitol, $\mathrm{pH}$ 6.25) and aliquots were stored at $-80^{\circ} \mathrm{C}$. EROD and MROD activities were measured using a modification of methods described by Kennedy and Jones (1994). The assays were optimized and conducted in 96-well plates (Corning Costar Corp., Corning, NY, USA), in which both microsomal cytochrome P450 activity and protein concentration were measured simultaneously using a Fluoroscan Ascent microplate fluorometer (Thermo Fisher Scientific Inc., Waltham, MA, USA). For EROD assays, the range of the working resorufin standards was $0-210 \mathrm{pmol} / \mathrm{well}$. The reaction mixture included $3.0 \mu \mathrm{L}$ of microsome preparation in $0.05 \mathrm{M}$ HEPES buffer (pH 7.8), $0.3 \mathrm{mM} \mathrm{NADPH}$, and $5 \mu \mathrm{M}$ 7-ER per well. For MROD assays, the working resorufin standard range was $0-180 \mathrm{pmol} / \mathrm{well}$. The reaction mixture included $8 \mu \mathrm{L}$ of microsome preparation in $0.05 \mathrm{M}$ HEPES buffer ( $\mathrm{pH}$ 7.8), $0.3 \mathrm{mM} \mathrm{NADPH}$, and $2.5 \mu \mathrm{M}$ of 7 -MR per well. Following the addition of the substrates (7-ER or 7-MR), all assay plates were preincubated for $10 \mathrm{~min}$ at $37^{\circ} \mathrm{C}$ prior to the addition of NADPH to initiate the reaction. EROD and MROD activities were determined kinetically by measuring the formation of resorufin every $2 \mathrm{~min}$ for $30 \mathrm{~min}$. The reaction was terminated by adding $60 \mu \mathrm{L}$ acetonitrile (Burdick \& Jackson, Muskegon, MI, USA) containing $0.4 \mathrm{mM}$ fluorescamine (Sigma-Aldrich, St. Louis, MO, USA) to each well, followed by the determination of protein concentrations (Kennedy and Jones 1994). EROD and MROD activities were determined from the linear range of the time curves for each well and the results were expressed as picomoles of substrate converted per minute per milligram of protein ( $\mathrm{pmol} / \mathrm{min} / \mathrm{mg})$.

Quantification of PCDD, PCDF, and TEQ

To ensure that co-contaminants were not a factor in the study, the concentrations of 17 individual 2,3,7,8-substituted PCDF and PCDD congeners and 12 individual PCB congeners were measured in the dietary items and mink tissues as described in Zwiernik et al. (2008b). Concentrations of TEQ were calculated as the sum of the products of the concentrations of congeners multiplied by their respective TEF (Van den Berg et al. 2006). A surrogate value of one-half the method detection limit (MDL) was used for concentrations less than the MDL.
Data Analysis

All statistical analyses were performed with SAS (Version 9.1; SAS, Cary, NC, USA). Because of the nature of the parameters, several statistical models were used for data analyses. The study was designed for the application of both fixed-effects models (test for differences among exposure groups) and regression analysis (correlation of liver PeCDF and TCDF concentrations and EROD and MROD enzyme activities). Prior to conducting statistical comparisons, data were tested for normality using the Shapiro-Wilkes test and probability plots. If necessary, values were log-transformed to approximate normality. Differences among exposure groups were tested using a one-way ANOVA followed by Dunnett's test (PROC ANOVA). A sensitivity analysis was conducted to determine the bias introduced by assuming a value of half the limit of quantification (LOQ) for censured data sets.

\section{Results}

\section{PCDF Concentrations in Liver}

Concentrations of TCDF and PeCDF in livers of mink fed daily doses of TCDF, PeCDF, or a mixture of the two congeners did not differ between 90 and 180 days; thus, a single mean concentration is presented (Table 1). Concentrations of TCDF in the liver varied among doses, ranging from $30 \%$ greater than the daily dose $(0.98$ $\mathrm{TEQ}_{\mathrm{TCDF}} / \mathrm{kg}$ body weight (bw)/day) to $65 \%$ less than the daily dose $\left(20 \mathrm{TEQ}_{\mathrm{TCDF}} / \mathrm{kg}\right.$ bw/day). Concentrations of PeCDF in mink liver increased significantly with dose, with bioaccumulation factors (BAFs) of 67 and 179 for the two doses (0.62 and $9.5 \mathrm{ng} \mathrm{TEQ}_{\mathrm{PeCDF}} / \mathrm{kg}$ bw/day, respectively). Concentrations of TCDF and PeCDF in livers of mink fed the TCDF/PeCDF mixture were similar to concentrations in the livers of mink receiving a similar dose of the individual congeners. Hepatic BAFs based on TEQ concentration were 0.34 for TCDF (4.1 ng $\mathrm{TEQ}_{\mathrm{TCDF}} / \mathrm{kg}$ bw/day) and 130 for PeCDF (2.8 ng TEQ PeCDF $_{1} / k g$ bw/day).

\section{Gross Morphology and Histology}

There were no treatment-related changes in gross morphology or histology. No external lesions or abnormalities that were attributable to treatment were observed, and the nutritional status of all mink, except for one individual, was classified as "good" to "very good." There were no significant changes in body mass or liver mass over the course of the study (data not presented). The most frequent histological alteration was hepatocellular vacuolation that occurred in all groups and, thus, was not considered to be 
treatment related (Table 2). There were a few cases of bile duct hyperplasia and minimal to mild mineralization of renal medullary tubules that occurred across all treatments. There was a numerically greater incidence of fatty liver in mink fed only PeCDF compared to the other groups (Table 2). Periodontitis was observed in one mink from the control group, but this was considered incidental and not treatment related. Jaw lesions classified as mild were observed at the termination of the study in two mink from the 9.5-ng TEQ ${ }_{\mathrm{PeCDF}} / \mathrm{kg}$ bw/day treatment group (Table 2). One of these mink exhibited a single cyst consisting of squamous epithelial cells (Fig. 1). However, the presence and severity of this lesion was not dose dependent and, therefore, was considered incidental.

\section{EROD and MROD Activities}

Mink fed TCDF alone had significantly greater EROD and MROD activities in the liver compared to controls. Because there were no significant treatment by time interactions, enzyme activities measured after 90 and 180 days of exposure were averaged. Exposure to TCDF resulted in

Table 2 Incidence of gross and histological effects in female mink exposed to either TCDF or PeCDF singly or as a mixture through the diet for up to 180 days

\begin{tabular}{|c|c|c|c|c|c|c|c|c|}
\hline \multirow[b]{2}{*}{ Pathological end points ${ }^{\mathrm{a}}$} & \multirow[b]{2}{*}{ Control } & \multicolumn{3}{|c|}{ TCDF (ng TEQ/kg bw/day) } & \multicolumn{3}{|c|}{ PeCDF (ng TEQ/kg bw/day) } & \multirow{2}{*}{$\begin{array}{l}\text { TCDF/PeCDF } \\
\text { Mixture }^{\mathrm{b}}\end{array}$} \\
\hline & & 0.98 & 3.8 & 20 & 0.62 & 2.2 & 9.5 & \\
\hline \multicolumn{9}{|l|}{ Oral lesions } \\
\hline Squamous epithelial osteoinvasion & 0 & 0 & 0 & 0 & 0 & 0 & 1 & 0 \\
\hline Osetoclasts and bone resorption & 0 & 0 & 0 & 0 & 0 & 0 & 1 & 0 \\
\hline Periodontitis & 1 & 0 & 0 & 0 & 0 & 0 & 0 & 0 \\
\hline \multicolumn{9}{|l|}{ Liver } \\
\hline Hepatocellular vacoulation & 5 & 6 & 6 & 6 & 6 & 6 & 6 & 6 \\
\hline Periportal lymphocytic/plasmytic & 0 & 0 & 1 & 0 & 0 & 0 & 0 & 0 \\
\hline Fatty liver & 0 & 1 & 0 & 1 & 1 & 3 & 2 & 0 \\
\hline Bile duct hyperplasia & 0 & 0 & 1 & 0 & 1 & 1 & 0 & 0 \\
\hline \multicolumn{9}{|l|}{ Kidney } \\
\hline Medullary tubules or uroliths & 1 & 1 & 1 & 1 & 0 & 1 & 1 & 2 \\
\hline Infection & 0 & 0 & 1 & 0 & 0 & 0 & 0 & 1 \\
\hline Nephritis & 0 & 1 & 0 & 0 & 0 & 0 & 0 & 0 \\
\hline Lymphoid aggregates & 0 & 0 & 0 & 0 & 0 & 2 & 0 & 0 \\
\hline \multicolumn{9}{|l|}{ Spleen } \\
\hline Hemorrhage & 0 & 0 & 0 & 0 & 0 & 0 & 0 & 1 \\
\hline Scar fissure & 1 & 0 & 0 & 0 & 0 & 0 & 0 & 0 \\
\hline
\end{tabular}

Note: Treatment concentrations are estimated daily doses reported as TEQ values. Mammalian TEF used were 0.3 for PeCDF and 0.1 for TCDF (Van den Berg et al. 2006)

${ }^{\text {a }}$ Values given for each end point represent the number of findings (mink) associated with each treatment group $(n=6$ mink per treatment, $n=8$ control)

b Mixture consisted of 4.1 and $2.8 \mathrm{ng}$ TEQ/kg bw/day for TCDF and PeCDF, respectively

Fig. 1 A single cyst consisting of squamous epithelial cells within the mandibular tissue at $4 \times($ a) and at $20 \times($ b). The arrow identifies the nest of cells proximal to the incisors
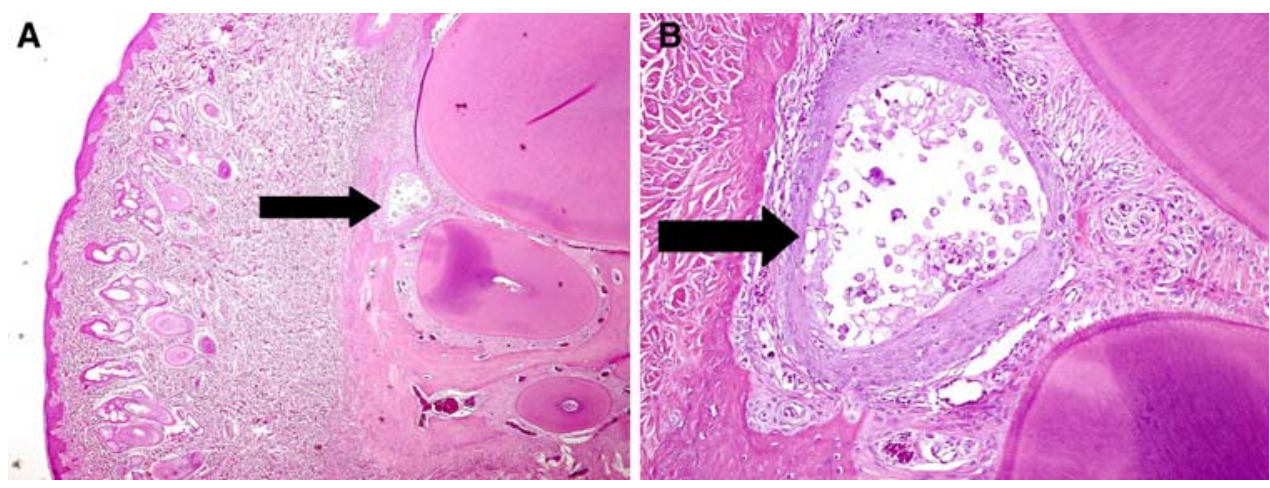

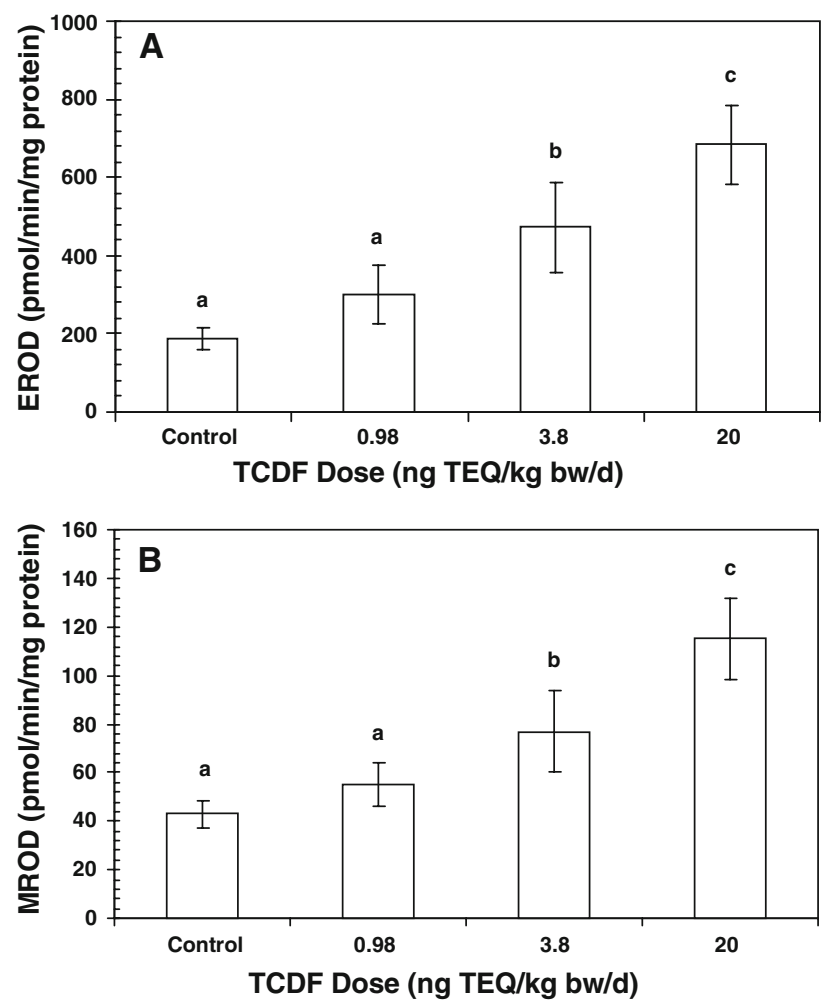

Fig. 2 Effects of TCDF on liver (a) EROD and (b) MROD activity in mink exposed for up to 180 days via the diet. Data are presented as means with error bars indicating standard deviations. Different letters indicate significant differences $(p<0.05)$ between dose groups. Control $n=8$ and each TCDF dose $n=6$

significantly greater activities of both EROD and MROD in mink at doses of 3.8 and $20 \mathrm{ng} \mathrm{TEQ}_{\mathrm{TCDF}} / \mathrm{kg}$ bw/day (Fig. 2). Additionally, EROD and MROD activities in mink fed $20 \mathrm{ng} \mathrm{TEQ}_{\mathrm{TCDF}} / \mathrm{kg}$ bw/day were significantly greater than activities of those fed $3.8 \mathrm{ng} \mathrm{TEQ}_{\mathrm{TCDF}} / \mathrm{kg}$ bw/day. Both EROD (Fig. 3a) and MROD (Fig. 3b) activities were positively correlated with concentrations of TCDF expressed as TEQ in the liver.

Exposure to PeCDF resulted in statistically significant greater EROD and MROD activities relative to controls (Fig. 4). Because there were no statistically significant differences in either EROD or MROD enzyme activities at 90 and 180 days and there were no interactions between treatment and the time the values of each of these enzyme activities at the two times were averaged. EROD activities in all PeCDF-dosed groups were significantly greater than control activity (Fig. 4a). EROD activity in the $9.5 \mathrm{ng}$ $\mathrm{TEQ}_{\mathrm{PeCDF}} / \mathrm{kg}$ bw/day group was significantly greater than enzyme activities in the 0.62 and $2.3 \mathrm{ng} \mathrm{TEQ}_{\mathrm{PeCDF}} / \mathrm{kg}$ bw/ day dose groups. MROD activities were also significantly greater than control activities at all PeCDF doses, with activities in livers of mink fed 2.2 or $9.5 \mathrm{ng} \mathrm{TEQ}_{\mathrm{PeCDF}} / \mathrm{kg}$ bw/day being significantly greater than activities in livers of mink fed $0.62 \mathrm{ng}$ TEQ $\mathrm{PeCDF} / \mathrm{kg}$ bw/day. Both EROD
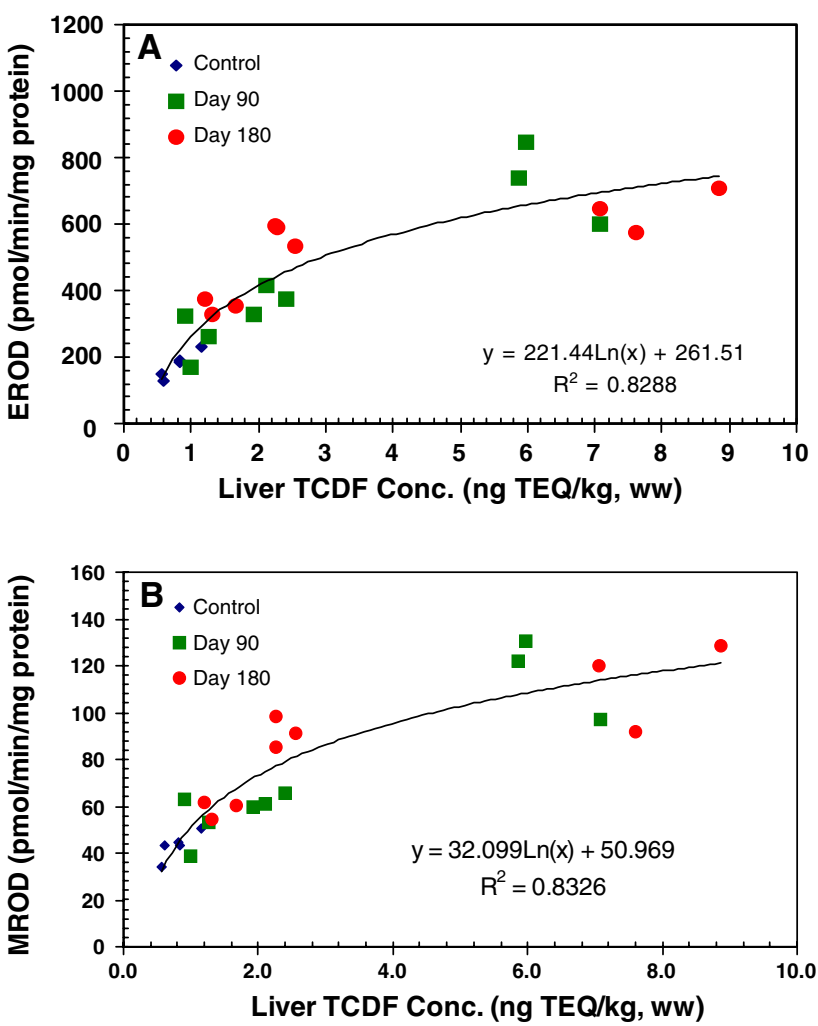

Fig. 3 Regression analysis between (a) EROD and (b) MROD activities and measured TCDF liver concentrations (ng TEQ $\mathrm{TCDF} / \mathrm{kg}$, ww) of mink exposed via the diet for 90 and 180 days. Models in the figures represent the best fit of the data based on criteria given in the Materials and Methods section

and MROD activities were positively correlated with concentrations of PeCDF expressed as TEQ in the liver (Fig. 5a and b).

The EROD and MROD activities in livers of mink fed a mixture of TCDF (4.1 ng TEQ $\mathrm{TCDF} / \mathrm{kg}$ bw/day) and PeCDF (2.8 ng $\mathrm{TEQ}_{\mathrm{PeCDF}} / \mathrm{kg}$ bw/day) were significantly greater than activities in livers of control mink (Fig. 6). EROD activity in the livers of mink fed the mixture of TCDF and PeCDF were similar to the activities in mink fed $3.8 \mathrm{ng}$ $\mathrm{TEQ}_{\mathrm{TCDF}} / \mathrm{kg}$ bw/day and those fed $2.2 \mathrm{ng}$ TEQ $\mathrm{PeCDF} / \mathrm{kg}$ bw/ day (Fig. 6a). MROD activity in livers of mink fed the mixture was significantly greater than enzyme activity in livers of mink fed $3.8 \mathrm{ng} \mathrm{TEQ}_{\mathrm{TCDF}} / \mathrm{kg}$ bw/day but did not differ from activity in livers of mink fed $2.2 \mathrm{ng}$ TEQ PeCDF kg bw/day PeCDF (Fig. 6b).

\section{Discussion}

PCDF Concentrations in Liver

2,3,4,7,8-Pentachlorodibenzofuran accumulated in the liver of the mink to a much greater extent than did TCDF when 

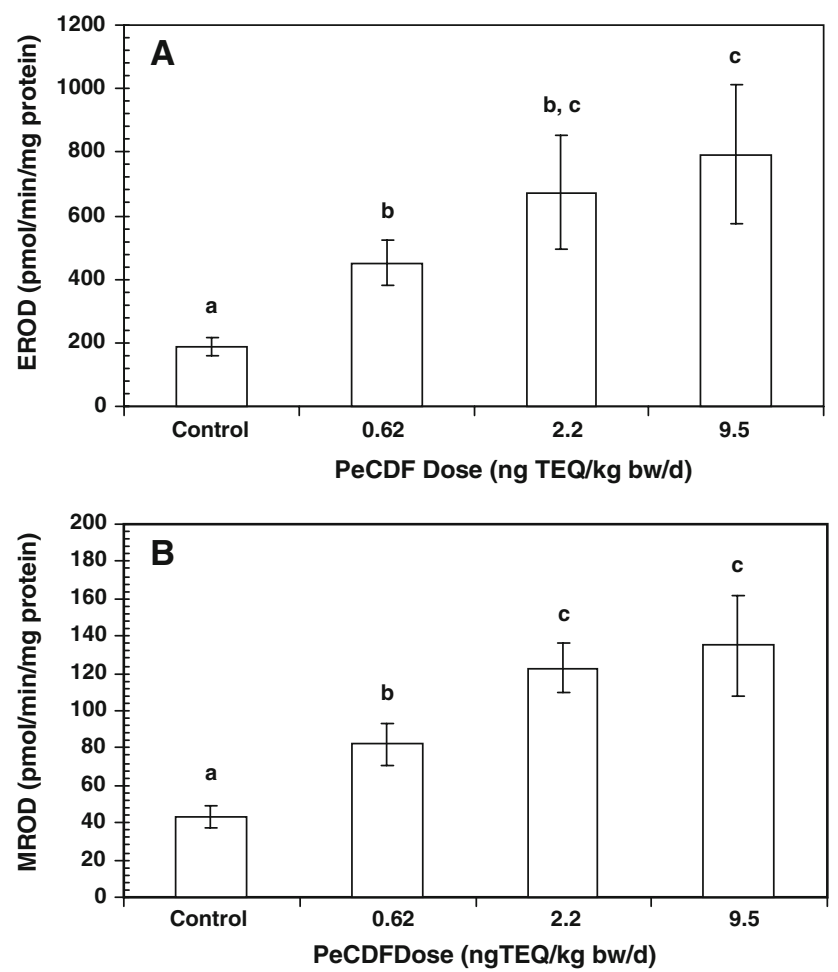

Fig. 4 Effects of PeCDF on liver (a) EROD and (b) MROD activities in mink exposed for up to 180 days via the diet. Data are provided as means with error bars indicating standard deviations. Different letters indicate significant differences $(p<0.05)$ between dose groups. Control $n=8$ and each PeCDF dose $n=6$

administered as a single congener or in combination with TCDF (Table 1). Hepatic sequestration of PeCDF relative to that of PCDDs and other PCDFs, including TCDF, is consistent with what has been reported in other studies with mammals (Brewster and Birnbaum 1987, 1988; DeVito et al. 1997). These studies have shown that PeCDF accumulates in the liver of rodents by binding to hepatic CYP1A2 protein (Diliberto et al. 1999) and, presumably, PeCDF could be sequestered in livers of mink by the same mechanism (Zwiernik et al. 2008b). The lesser concentrations of TCDF accumulated in livers of the mink suggest an efficient elimination and/or metabolism of the congener. The BAF of this congener has been reported to be inversely proportional to dose (Zwiernik et al. 2008b), which suggests inducible metabolism of TCDF. This is similar to what has been reported in rodents (Tai et al. 1993). The fact that the presence of PeCDF reduced the accumulation of TCDF in the liver of the mink to an even greater extent strengthens the argument that induction of CYP1A1 reduced accumulation of TCDF (Zwiernik et al. 2008b).

The whole-body half-time for elimination of PeCDF observed for mink in this study was estimated to be $\sim 8$ days, whereas the half-time for elimination of TCDF was less than half a day in mink (Zwiernik et al. 2008b). The half-time for elimination for TCDF and
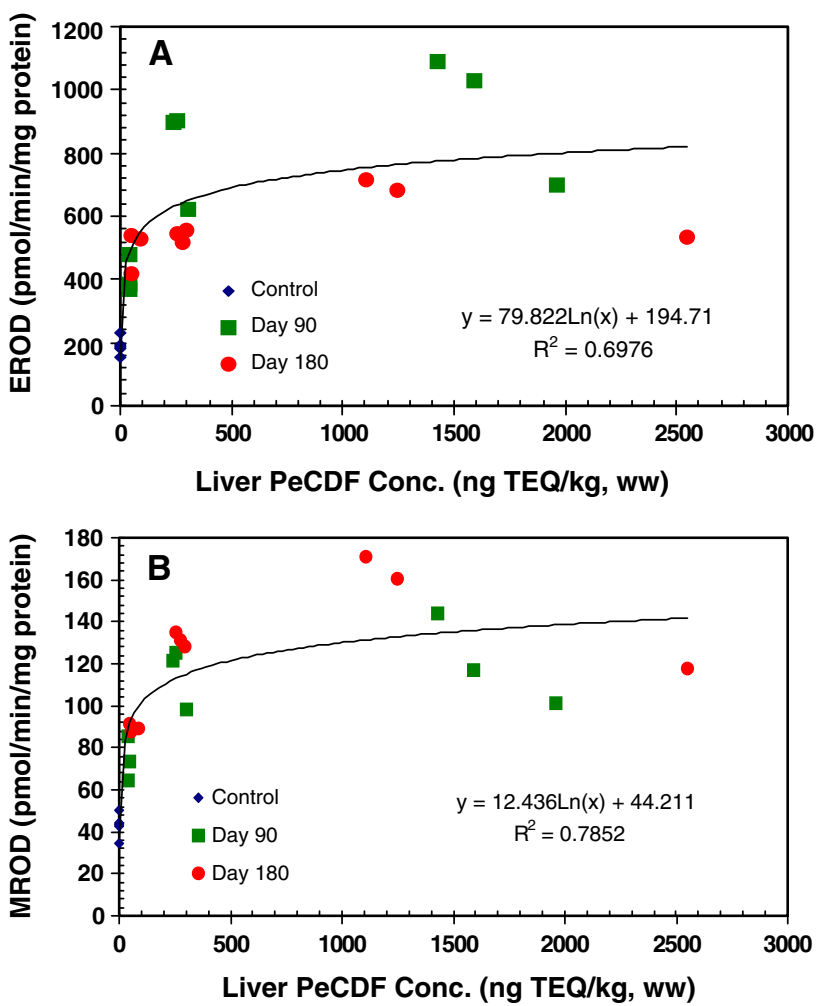

Fig. 5 Regression analysis between (a) EROD and (b) MROD activities and measured PeCDF liver concentrations (ng TEQ $\mathrm{PeCDF} /$ $\mathrm{kg}$, ww) of mink exposed via the diet for 90 and 180 days. Models in the figures represent the best fit of the data based on criteria given in the Materials and Methods section

PeCDF in the mink are less than those reported for rodents. The half-time of TCDF is $\sim 2$ days in mice (DeVito et al. $1997)$ and the half-time of PeCDF in the rat is more than 60 days (Brewster and Birnbaum 1987).

\section{Histology}

In this study, TCDF and PeCDF, administered singly or in combination, at environmentally relevant doses for 180 days did not result in changes in gross morphological or histological end points (Table 2) that have been reported for other studies in which mink were exposed to dioxin or dioxin-like compounds (Hochstein et al. 1988, 1998; Render et al. 2000a, 2000b, 2001). Recent studies (Bursian et al. 2006b, 2006c) suggest that a very sensitive indicator of exposure of mink to environmentally relevant concentrations of TCDD-like compounds is proliferation of mandibular and maxillary squamous epithelia. Previous studies have indicated that ranch mink exposed to $24.0 \mu \mathrm{g}$ of $3,3^{\prime}, 4,4^{\prime}, 5$-pentachlorobiphenyl (PCB 126)/kg feed or $2.4 \mu \mathrm{g} \mathrm{TCDD} / \mathrm{kg}$ feed $(2.4 \mu \mathrm{g} \mathrm{TEQ} / \mathrm{kg}$ feed or $\sim 300 \mathrm{ng}$ $\mathrm{TEQ} / \mathrm{kg}$ bw/day) developed clinical signs of mandibular and maxillary squamous epithelial hyperplasia that, in 

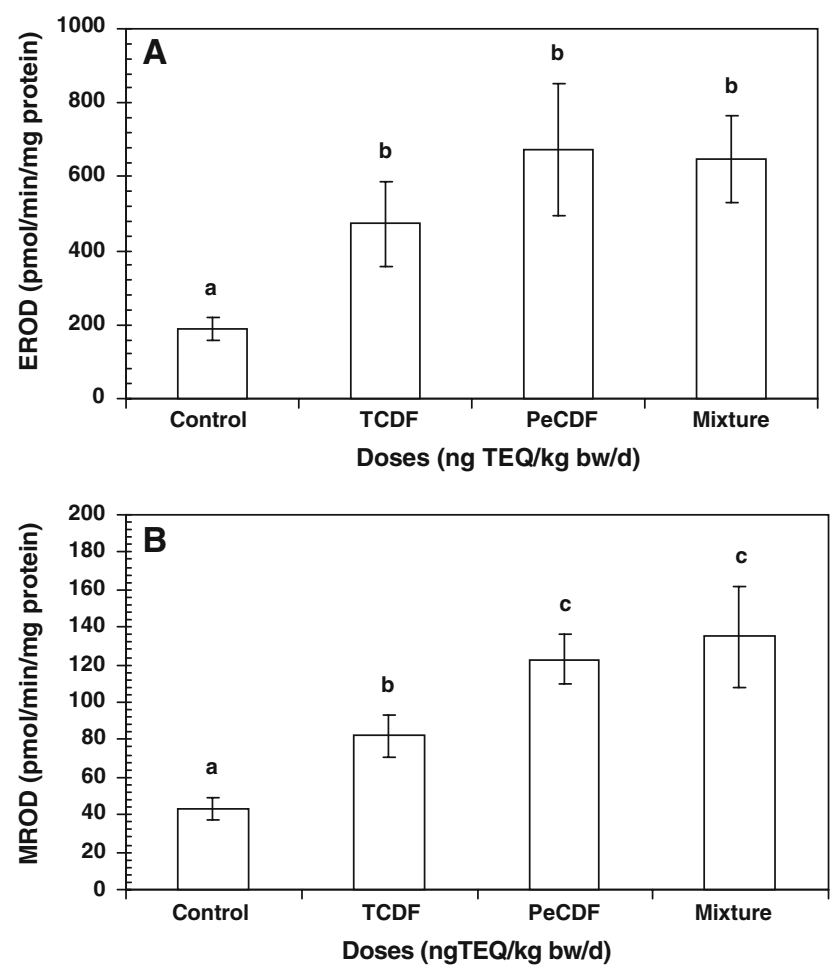

Fig. 6 Effects of mixture of TCDF (4.1 ng TEQ $\mathrm{TCDF} / \mathrm{kg}$ bw/day) and PeCDF (2.8 ng TEQ PeCDF $_{1} / \mathrm{kg}$ bw/day) on liver (a) EROD and (b) MROD activities in mink exposed for up to 180 days via the diet. Single TCDF and PeCDF doses are $3.8 \mathrm{ng} \mathrm{TEQ}_{\mathrm{TCDF}} / \mathrm{kg}$ bw/day and $2.2 \mathrm{ng} \mathrm{TEQ}_{\mathrm{PeCDF}} / \mathrm{kg}$ bw/day, respectively. Data are presented as means with error bars indicating standard deviations. Different letters indicate significant differences $(p<0.05)$ between treatments. Control $n=8, \mathrm{TCDF} n=6, \operatorname{PeCDF} n=6$, and mixture $n=5$

severe cases, resulted in the loss of teeth (Render et al. 2000a; 2001). Mink fed diets containing concentrations as little as $0.24 \mu \mathrm{g}$ PCB $126 / \mathrm{kg}$ feed $(0.024 \mu \mathrm{g}$ TEQ $/ \mathrm{kg}$ feed or $3 \mathrm{ng} \mathrm{TEQ} / \mathrm{kg}$ bw/day) (Beckett et al. 2008) exhibited the lesion (Beckett, personal communication), as did mink fed a diet containing fish containing PCBs, PCDDs, and PCDFs that provided an estimated daily dose of $1 \mathrm{ng}$ TEQ/ $\mathrm{kg}$ bw/day (Bursian et al. 2006b). In the present study, only one animal, which had been fed $9.5 \mathrm{ng} \mathrm{TEQ}_{\mathrm{PeCDF}} / \mathrm{kg}$ bw/ day, had a single cyst of squamous epithelial cells at 180 days. The concentration of PeCDF in the liver of that mink was $1.3 \mathrm{ng} \mathrm{TEQ} / \mathrm{g}$, ww (wet weight). In those mink studies in which jaw lesion incidence and liver TEQ concentrations were assessed, results indicated that histological lesions were evident in animals with hepatic TEQ concentrations ranging from 40 to $75 \mathrm{ng} / \mathrm{kg}$, ww in the liver (Bursian et al. 2006b, 2006c). Wild mink with histological evidence of proliferation of mandibular and maxillary squamous epithelia had an average concentration of $610 \mathrm{ng}$ TEQ/kg, ww (Beckett et al. 2005). There are two possible explanations for the scarcity of the jaw lesions in the present study. One possibility is that the age at which exposure was initiated was too late and/or the duration of exposure was not sufficient. In the studies with ranch mink in which effects were observed at concentrations similar or less than those tested in this study, exposure began in utero and continued until mink were $\sim 7$ months old (Bursian et al. 2006b, 2006c). In those studies in which exposure periods ranged from 30 to 60 days (Render et al. 2000a, 2001), the mink were approximately 6 weeks old and the dose was $\sim 30$-fold greater than the dose in the present study (300 ng TEQ/kg bw/day vs. $9.5 \mathrm{ng} \mathrm{TEQ} / \mathrm{kg}$ bw/day). A second possibility is related to the specific PCB/PCDD/ PCDF congeners contributing to the TEQs. In studies of ranch mink utilizing individual congeners, TEQs were provided by either TCDD or PCB 126 (Render et al. 2000a, 2000b, 2001). In those studies of mink fed diets containing contaminated fish, the majority of TEQs were contributed by congeners other than furans; for example, in a study that assessed the effects of feeding diets containing fish from the Housatonic River, PCB 126 and TCDD contributed $61 \%$ of the total TEQs and TCDF and PeCDF contributed 4\% (Bursian et al. 2006a, 2006b). In a similar study utilizing fish from the Saginaw River, PCB 126 and TCDD contributed $39 \%$ of the total and TCDF and PeCDF accounted for $25 \%$ of the total. It is possible that TCDF and PeCDF are less effective than PCB 126 and TCDD in inducing proliferation of mandibular and maxillary squamous epithelia. Furthermore, it has been determined that the effects of PCDFs cannot be accurately predicted from the use of TEQ-based TRVs developed from studies of PCDDs and PCBs (Blankenship et al. 2008). This suggests that there are differences in the sensitivity of mink to PCBs and PCDFs that are not appropriately reflected by the currently utilized TEQ approach (Van den Berg et al. 2006).

\section{Enzyme Induction}

Basal EROD activities measured in livers of mink during this study fell within a range of control activities that have been reported in other studies with mink (Brunström et al. 2001; Käkelä et al. 2001; Martin et al. 2007; Shipp et al. 1998; Smits et al. 1995). Values in this study were similar to those reported by Smits et al. (1995), Käkelä et al. (2001) and Martin et al. (2007) but were less than those values reported by Brunström et al. (2001). However, given the inconsistencies between all of these studies relative to experimental design, age, and sex of animals, as well as potential contaminants associated with their feed, a direct comparison among these studies is not possible. Given that the basal EROD activities in our study are similar to those enzyme activities measured in other studies, it can be assumed that the cytochrome P4501A1 system was functioning properly. 
To our knowledge, there have been no reports of MROD enzyme activities in mink to date. Basal MROD activity was less than that reported for EROD, which is in accordance with studies in other mammals such as rats or monkeys (Lubet et al. 1990; Suzuki et al. 2001; Weaver et al. 1994) but opposite to reports on other species such as various mice strains, hamster, or humans (Hamm et al. 1998; Weaver et al. 1994). The relative difference between EROD and MROD activities was greater (approximately fivefold) when compared to that reported for rats or monkeys ( $<$ twofold to threefold). It has been previously reported that the specificities of orthologous forms of P450 s are expressed differently among mammalian species. In rats, CYP1A1 and CYP1A2 selectively catalyze EROD and MROD, respectively, whereas in humans, CYP1A2 has similar activities for both EROD and MROD. From the data presented here it appears that mink are associated more closely with the rat or monkey regarding their basal EROD/MROD profiles. However, further elucidation of the specificities of different forms of P450 s for the different alkylresorufin $O$-dealkylases (AROD) is necessary to be able to assign mink to a certain mammalian metabolism type.

There were no significant differences in enzyme activity in mink receiving daily doses of TCDF and/or PeCDF between 90 and 180 days. This suggests that maximum induction of CYP1As in livers of mink as a function of time in response to the exposure with TCDF and PeCDF occurs earlier than the first sampling time point at 90 day.

The EROD activity in mink dosed with the mixture of TCDF and PeCDF was similar to enzyme activity in those mink dosed with either TCDF or PeCDF, whereas MROD activity was similar to activity in those mink dosed with PeCDF. This suggests that induction resulting from the combination of the two furan congeners might not have been additive and perhaps was due primarily to the action of only one of the congeners. Based on liver concentration data indicating greater concentration of PeCDF compared to TCDF, it is possible that enzyme induction in those animals receiving the mixture was due primarily to PeCDF. Alternatively, TCDF might also have contributed to the increase in enzyme activities, but due to metabolism, its concentration in the liver was less than that of PeCDF.

\footnotetext{
Acknowledgments This research was supported by an unrestricted grant from ENTRIX Inc. to Steven J. Bursian, John P. Giesy, and Matthew J. Zwiernik. Professor Giesy was supported by an at-large Chair Professorship at the Department of Biology and Chemistry and Research Centre for Coastal Pollution and Conservation, City University of Hong Kong and by an "Area of Excellence" Grant (AoE P04/04) from the Hong Kong University Grants Committee. Special thanks go to Angelo Napolitano, Jeff Greenlee, C.P. Napolitano, David Hamman, Patrick Bradley, Michael Kramer, Nozomi Ikeda, Molly Wiersema, and Melissa Shotwell for the expertise and support they provided during the study.
}

Open Access This article is distributed under the terms of the Creative Commons Attribution Noncommercial License which permits any noncommercial use, distribution, and reproduction in any medium, provided the original author(s) and source are credited.

\section{References}

Basu N, Scheuhammer AM, Bursian SJ, Elliott J, Rouvinen-Watt K, Chan HM (2007) Mink as a sentinel species in environmental health. Environ Res 103:130-144. doi:10.1016/j.envres.2006.04. 005

Beckett KJ, Millsap SD, Blankenship AL, Zwiernik MJ, Giesy JP, Bursian SJ (2005) Squamous epithelial lesion of the mandibles and maxillae of wild mink (Mustela vison) naturally exposed to polychlorinated biphenyls. Environ Toxicol Chem 24:674-677. doi:10.1897/04-241R.1

Beckett KJ, Yamini B, Bursian SJ (2008) The effects of 3,3',4,4'5pentachlorobiphenyl (PCB 126) on mink (Mustela vison) reproduction and kit survivability and growth. Arch Environ Contam Toxicol 54:123-129. doi:10.1007/s00244-007-9002-8

Blankenship AL, Kay DP, Zwiernik MJ et al (2008) Toxicity reference values for mink exposed to 2,3,7,8-tetrachlorodibenzop-dioxin. Ecotoxicol Environ Safety 69:325-349. doi:10.1016/ j.ecoenv.2007.08.017

Brewster DW, Birnbaum LS (1987) 2,3,4,7,8-Pentachlorodibenzofuran (PCDF): toxicokinetics and metabolism in the rat. Environ Health Perspect 75:147-148

Brewster DW, Birnbaum LS (1988) The acute toxicity of 2,3,4,7,8pentachlorodibenzofuran (4-PeCDF) in the male Fisher rat. Fundam Appl Toxicol 11:236-249. doi:10.1016/0272-0590(88) 90148-0

Brunström B, Lund BO, Bergman A et al (2001) Reproductive toxicity in mink (Mustela vison) chronically exposed to environmentally relevant polychlorinated biphenyl concentrations. Environ Toxicol Chem 20:2318-2337. doi:10.1897/15515028(2001)020<2318:RTIMMV >2.0.CO;2

Bursian SJ, Aulerich RJ, Yamini B, Tillitt DE (2006a) Dietary exposure of mink (Mustela vison) to fish from the Housatonic River, Berkshire County, Massachusetts, USA: effects on reproduction, kit growth, and survival. Environ Toxicol Chem 25:1533-1540. doi:10.1897/05-406R.1

Bursian SJ, Aulerich RJ, Yamini B, Tillitt DE (2006b) Dietary exposure of mink (Mustela vison) to fish from the Housatonic River, Berkshire County, Massachusetts, USA: effects on organ weights and histology and hepatic concentrations of polychlorinated biphenyls and 2,3,7,8-tetrachlorodibenzo- $p$-dioxin toxic equivalence. Environ Toxicol Chem 25:1541-1550. doi:10.1897/ 05-407R.1

Bursian SJ, Beckett KJ, Yamini B et al (2006c) Assessment of effects in mink caused by consumption of carp collected from the Saginaw River, Michigan, USA. Arch Environ Contam Toxicol 50:614-623. doi:10.1007/s00244-005-1136-y

DeVito M, Diliberto J, Ross DG, Menache MG, Birnbaum L (1997) Dose-response relationships for polyhalogenated dioxins and dibenzofurans following subchronic treatment in mice I. CYP1A1 and CYP1A2 enzyme activity in liver, lung, and skin. Toxicol Appl Pharm 147:267-280. doi:10.1006/taap.1997.8261

Diliberto JJ, Burgin DE, Birnbaum LS (1999) Effects of CYP1A2 on disposition of 2,3,7,8-tetrachlorodibenzo- $p$-dioxin, 2,3,4,7,8-tetrachlorodibenzofuran, and 2,2'4,4',5,5'-hexachlorobiphenyl in CYP1A2 knockout and parental (C57BL/6 N and 129/Sv) strains of mice. Toxicol Appl Pharmacol 159:52-64. doi:10.1006/taap. 1999.8720 
Giesy JP, Verbrugge DA, Othout RA et al (1994) Contaminants in fishes from Great Lakes-influenced sections and above dams of three Michigan rivers. II: implications for health of mink. Arch Environ Contam Toxicol 27:213-223

Hahn ME (1998) The aryl hydrocarbon receptor: a comparative perspective. Comp Biochem Physiol C Pharmacol Toxicol Endocrinol 121:23-53. doi:10.1016/S0742-8413(98)10028-2

Hamm JT, Ross DG, Richardson VM, Diliberto JJ, Birnbaum LS (1998) Methoxyresorufin: an inappropriate substrate for CYP1A2 in the mouse. Biochem Pharmacol 56:1657-1660. doi: 10.1016/S0006-2952(98)00241-X

Hilscherova K, Kannan K, Nakata H et al (2003) Polychlorinated dibenzo- $p$-dioxin and dibenzofuran concentration profiles in sediments and flood-plain soils of the Tittabawassee River, Michigan. Environ Sci Technol 37:468-474. doi:10.1021/ es020920c

Hochstein JR, Aulerich RJ, Bursian SJ (1988) Acute toxicity of 2,3,7,8-tetrachlorodibenzo-p-dioxin to mink. Arch Environ Contam Toxicol 17:33-37. doi:10.1007/BF01055151

Hochstein JR, Bursian SJ, Aulerich RJ (1998) Effects of dietary exposure to 2,3,7,8-tetrachlorodibenzo-p-dioxin in adult female mink. Arch Environ Contam Toxicol 15:348-353. doi:10.1007/ s002449900386

Käkelä R, Jokinen I, Käkelä A, Hyvärinen H (2001) Effects of gender, diet, exogenous melatonin and subchronic PCB exposure on plasma immunoglobulin $\mathrm{G}$ in mink. J Toxicol Environ Health A 64:427-446. doi:10.1080/152873901753170759

Kawajiri K, Fujii-Kuriyama Y (2007) Cytochrome P450 gene regulation and physiological functions mediated by the aryl hydrocarbon receptor. Arch Biochem Biophys 464:207-212. doi: 10.1016/j.abb.2007.03.038

Kennedy SW, Jones SP (1994) Simultaneous measurement of cytochrome P4501A catalytic activity and total protein concentration with a fluorescence plate reader. Anal Biochem 222:217223. doi:10.1006/abio.1994.1476

Lubet RA, Syi JL, Nelson JO, Nims RW (1990) Induction of hepatic cytochrome P-450 mediated alkoxyresorufin $O$-deethylase activities in different species by prototype P450 inducers. Chem Biol Interact 75:325-339. doi:10.1016/0009-2797(90)90075-X

Martin PA, Mayne G, Bursian SJ et al (2007) Immunotoxicity of the commercial polybrominated diphenyl ether mixture DE-71 in ranch mink (Mustela vison). Environ Toxicol Chem 26:988-997. doi:10.1897/06-246R.1

Render JA, Aulerich RJ, Bursian SJ, Nachreiner RF (2000a) Proliferation of maxillary and mandibular periodontal squamous cells in mink fed 3,3',4,4',5-pentachlorobiphenyl (PCB 126). J Vet Diagn Invest 12:477-479

Render JA, Bursian SJ, Rosenstein DS, Aulerich RJ (2001) Squamous epithelial proliferation in the jaws of mink fed diets containing $3,3^{\prime}, 4,4^{\prime}, 5$-pentachlorobiphenyl (PCB 126) or 2,3,7,8-tetrachlorodibenzo- $p$-dioxin (TCDD). Vet Hum Toxicol 43:22-26
Render JA, Hochstein JR, Aulerich RJ, Bursian SJ (2000b) Proliferation of periodontal squamous epithelium in mink fed 2,3,7,8-tetrachlorodibenzo-p-dioxin (TCDD). Vet Hum Toxicol 42:85-86

Shipp EB, Restum JC, Giesy JP, Bursian SJ, Aulerich RJ, Helferich WG (1998) Multigenerational study of the effects of consumption of PCB-contaminated carp from Saginaw Bay, Lake Huron on mink. 2. Liver PCB concentration and induction of hepatic cytochrome P-450 activity as a potential biomarker for PCB exposure. J Toxicol Environ Health 54A:377-401. doi:10.1080/ 009841098158809

Smits JEG, Wobeser GA, Schiefer B (1995) Physiological, reproductive and pathological effects of dietary bleached pulp mill effluent on mink. Environ Toxicol Chem 14:2095-2105. doi: 10.1897/1552-8618(1995)14[2095:PRAPEO]2.0.CO;2

Suzuki T, Nakagawa Y, Tayama K, Yaguchi K, Suga T (2001) Toxicity and effects of 2,6,-di-tert-butyl-4-methylphenyl Nmethylcarbamate (terbutol) on hepatic cytochrome P450 in F344 rats. Arch Toxicol 75:555-561. doi:10.1007/s002040100254

Tai HL, McReynolds JH, Goldstein JA et al (1993) Cytochrome P4501A1 mediates metabolism of 2,3,7,8-tetrachlorodibenzofuran in the rat and human. Toxicol Appl. Pharmacol 123:34-42. doi:10.1006/taap.1993.1218

Tillitt DE, Gale RW, Meadows JC et al (1996) Dietary exposure of mink to carp from Saginaw Bay. 3. Characterization of dietary exposure to planar halogenated hydrocarbons, dioxin equivalents, and biomagnification. Environ Sci Technol 30:283-291. doi:10.1021/es 9503140

Van den Berg M, Birnbaum LS, Denison M et al (2006) The 2005 World Health Organization reevaluation of human and mammalian toxic equivalency factors for dioxins and dioxin-like compounds. Toxicol Sci 93:223-241. doi:10.1093/toxsci/kfl055

Weaver RJ, Thompson S, Smith G et al (1994) A comparative study of constitutive and induced alkoxyresorufin O-dealkylation and individual cytochrome $\mathrm{P} 450$ forms in cynomolgus monkey (Macaca fascicularis), human, mouse, rat and hamster liver microsomes. Biochem Pharmacol 47:763-773. doi:10.1016/00 06-2952(94)90475-8

Whitlock JP Jr (1999) Induction of cytochrome P4501A1. Annu Rev Pharmacol Toxicol 39:103-125. doi:10.1146/annurev.pharmtox. 39.1.103

Zwiernik MJ, Kay DP, Moore JN, et al. (2008a) Exposure and effects assessment of resident mink exposed to polychlorinated dibenzofurans and other dioxin-like compounds in the Tittabawassee River Basin, Midland, MI, USA on wild mink (Mustela vison). Environ Toxicol Chem 27:2076-2087. doi: 10.189/07-489.1

Zwiernik MJ, Bursian SJ, Aylward LL, et al. (2008b) Toxicokinetics of 2,3,7,8-TCDF and 2,3,4,7,8-PeCDF in mink (Mustela vison) at ecologically relevant exposures. Toxicol Sci 105:34-43 doi: $10.1093 /$ toxsci/kfn118 